JPSCR: Journal of Pharmaceutical Science and Clinical Research, 2021, 03, 287-294

DOI: $10.20961 /$ jpscr.v6i3.51930

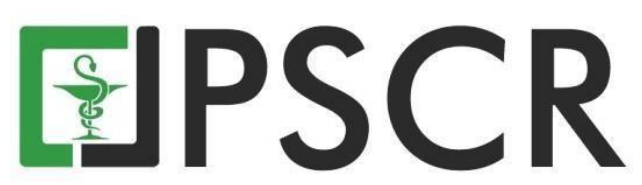

\title{
Kepatuhan Pengobatan Terhadap Indeks Glikemik Kontrol Pada Pasien Diabetes Melitus Tipe II di Rumah Sakit Islam Sultan Agung Semarang
}

\author{
Nur Anna Chalimah Sa'dyah ${ }^{1}$, Farroh Bintang Sabiti ${ }^{*}$ dan Sandra Thertianing Susilo ${ }^{3}$ \\ ${ }^{1}$ Bagian Fakultas Kedokteran Universitas Islam Sultan Agung, Jl. Kaligawe Raya No.Km 4, Semarang, Indonesia, \\ 50112. \\ ${ }^{2}$ Bagian Farmasi Klinik dan Komunitas Program Studi Farmasi Fakultas Kedokteran Universitas Islam Sultan \\ Agung Jl. Kaligawe Raya No.Km 4, Semarang, Indonesia, 50112. \\ ${ }^{3}$ Mahasiswa Program Studi Farmasi Fakultas Kedokteran Universitas Islam Sultan Agung Jl. Kaligawe Raya \\ No.Km 4, Semarang, Indonesia, 50112. \\ *email korespondensi: farrahbintang@unissula.ac.id \\ Received 11 June 2021, Accepted 13 October 2021, Published 15 November 2021
}

\begin{abstract}
Abstrak: Diabetes Melitus ialah penyakit yang ditandai dengan nilai kadar $\mathrm{HbA1c}>7 \%$. Hampir 80\% pasien Diabetes Mellitus Tipe II mengalami kematian. Kepatuhan dalam meminum obat merupakan peran penting bagi penderita penyakit Diabetes Melitus tipe II. Perlu adanya peningkatan kepatuhan dalam penggunaan obat sehingga keberhasilan dalam pengobatan tercapai serta nilai kadar indeks glikemik yang terkontrol. Tujuan penelitian ini adalah untuk mengetahui hubungan kepatuhan penggunaan obat dengan indeks glikemik kontrol pada pasien Diabetes Melitus di Rumah Sakit Islam Sultan Agung Semarang. Penelitian ini merupakan penelitian pra-eksperimental dengan rancangan The one Group Pretest-Posttes dilakukan secara cross sectional. Sampel sebanyak 96 pasien yang diberikan kuisioner kepatuhan ARMS diambil di Rumah Sakit Islam Sultan Agung Semarang Pengambilan data dilakukan pada periode Agustus-Oktober 2020 di Rumah Sakit Islam Sultan Agung Semarang. Penelitian ini didapatkan hasil 0,000 yang dikatakan terdapat indeks glikemik kontrol HbA1c pada pasien Diabetes Melitus type II di Rumah Sakit Islam Sultan Agung Semarang menunjukan nilai $p$ 0,000 $(p<0,05)$ bahwa terdapat hubungan kepatuhan penggunaan obat dengan Indeks glikemik kontrol kadar HbA1c.
\end{abstract}

Kata Kunci: $A R M S$; Diabetes Mellitus; HbA1c; kepatuhan

Abstract. Compliance of Drugs With The Glychemic Index Control Of Type II Diabetes Mellitus At Sultan Agung Semarang Islamic Hospital. Diabetes mellitus is a disease characterized by HbAlc levels $>7 \%$. Nearly $80 \%$ of Diabetes Mellitus Type II patients experience death. Adherence in taking medication is an important role for people with diabetes mellitus type II. It is necessary to increase adherence in drug use so that success in treatment is achieved and the value of the glycemic index levels is controlled. The purpose of this study was to determine the relationship between drug use adherence and glycemic index control in Diabetes Mellitus patients at Sultan Agung Islamic Hospital Semarang. This research is a preexperimental study with the design of The one Group Pretest-Posttest conducted by cross sectional. A sample of 96 patients who were given the ARMS compliance questionnaire was taken at the Sultan Agung Islamic Hospital in Semarang. Data collection was carried out in the August-October 2020 period at the Sultan Agung Islamic Hospital Semarang. This study result showed 0,000 which said there was a significant difference before and after drug administration and the chi square test found 0,000 $(p<0,05)$ results which said that there was a significant relationship between drug use adherence and the glycemic index control in diabetes patients. Mellitus type II.

Keywords: $A R M S$; Diabetes Mellitus; HbA1c; compliance 


\section{Pendahuluan}

Diabetes Melitus tipe II ialah penyakit tidak menular serta bersifat kronik sehingga perlu adanya pemantauan dalam terapi serta perlu perhatian dalam meminum obat agar mencapai keberhasilan pengobatan untuk menjaga kadar HbA1c dan kadar GDS (gula darah sewaktu) serta kadar GDP (gula darah puasa) pada pasien (Sivasubramanian et al., 2019). Indonesia termasuk peringkat 6 angka kejadian Diabetes Melitus tipe II didunia. Pada tahun 2019 terdapat 463 juta orang menderita Diabetes Melitus tipe II. Menurut RISKEDAS tahun 2018 prevaensi Diabetes Melitus tipe II di Indonesia sebesar 21,8\% (PERKENI, 2019).

Data prevalensi untuk Provinsi Jawa Tengah pada tahun 2017 sebesar 1,9\%. Jumlah kasus Diabetes Melitus tipe II yang terjadi di Jawa Tengah berbeda-beda setiap tahunnya. Tahun 2015 merupakan tahun dengan kasus Diabetes Melitus tipe II terbesar daripada 3 tahun sebelumnya. kasus Diabetes Melitus tipe II pada tahun 2015 di Jawa Tengah sebanyak 99.646 kasus (Aini, 2016).

Kepatuhan merupakan tindakan atau suatu program yang menjadi tanggung jawab pasien dan harus dijalankan sepanjang kehidupannya (Katadi et al., 2019). Kepatuhan dalam penggunaan obat pada pasien Diabetes Melitus tipe II bertujuan untuk mengontrol indeks glikemik kontrol (kadar HbA1c), serta klinikal output lainnya secara optimal dan mencegah timbulnya komplikasi (Nanda et al., 2018). Penyebab ketidakpatuhan meminum obat diantaranya disebabkan oleh kesibukan pasien sehingga pasien lupa meminum obat, pasien merasa tidak cepat sembuh (Srikartika et al., 2016). Kemudian, efek samping yang timbul dari obat yang dikonsumsi sehingga pasien tidak memiliki semangat dalam pengobatan penyakit Diabetes Melitus tipe II (Nurul, 2014). Adherence dapat diukur menggunakan metode tidak langsung yakni dengan Pasienself report diukur dengan menggunakan kuisioner sedangkan, pengukuran langsung dapat digunakan dengan pengukuran kadar HbA1c pasien (Adikusuma \& Qiyaam, 2017). Kuisioner ARMS tepat digunakan untuk mengukur kepatuhan penggunaan obat terhada penderita penyakit kronik termasuk penyakit Diabetes Melitus tipe II. Pengukuran tingkat kepatuhan dengan menggunakan kuisioner memiliki kelebihan yakni relative murah, praktis dan efisien. Tingkat kepatuhan meminum obat pada pasien Diabetes Melitus Tipe II perlu diketahui sehinggaa dapat menjadi tolak ukur terkait jenis terapi dan intervensi terapi (Ernawati, 2010). Kuisioner ARMS merupakan kuisioner untuk mengukur kepatuhan penggunaan obat terdiri dari 12 pertanyaan dengan 8 item subskala menilai kemampuan pasien untuk mengatur sendiri resep dengan regimen yang benar, kemudian 4 item menilai kemampuan pasien untuk menggunakan ulang obat sesuai jadwal. Secara konseptual, kuisioner ini mewakili masalah dalam kepatuhan penggunaan obat. Setiap pertanyaan pada kuisioner ARMS dinilai dengan skala Likert dari skor 1 sampai skor 4. Skor 1 (tidak pernah), skor 2 (kadang-kadang), 
skor 3 (selalu), dan skor 4 (sering). Tingkat kepatuhan dikategorikan menjadi 3 yakni kepatuhan tinggi skor 12-16, kepatuhan sedang skor 17-32, dan kepatuhan rendah skor 33-48 (Kripalani et al., 2009).

Penelitian ini digunakan metode tidak langsung, dengan menggunakan Adherance Refill Medication Scale (ARMS). Metode Adherance Refill Medication Scale (ARMS) digunakan untuk mengukur tingkat kepatuhan pasien dalam penggunaan obat yang telah diberikan dokter (Kripalani et al., 2009). Penelitian hubungan kepatuhan penggunaan obat dengan kadar HbA1c pada pasien Diabetes Melitus tipe II di Rumah Sakit Islam Sultan Agung Semarang belum pernah dilakukan sebelumnya, maka dari itu penelitian ini perlu dilakukan. Tujuan dari penelitian ini yaitu untuk mengetahui hubungan kepatuhan penggunaan obat dengan indeks glikemik kontrol pada pasien Diabetes Melitus di Rumah Sakit Islam Sultan Agung Semarang pada periode Agustus-September 2020.

\section{Bahan dan Metode}

Jenis penelitian yang dipakai yaitu observasi analitik dengan metode cross sectional. Desain penelitian tersebut digunakan untuk memperoleh hubungan kepatuhan penggunaan obat dengan indeks glikemik kontrol pada pasien Diabetes Melitus tipe II. Populasi dalam penelitian yaitu semua pasien penderitan Diabetes Melitus tipe II di Rumah Sakit Islam Sultan Agung Semarang. Sampel yang diambil sebanyak 96 pasien yakni pasien Diabetes Melitus tipe II yang sudah memenuhi kategori inklusi di RS Islam Sultan Agung Semarang. Persetujuan etik untuk melakukan penelitian diperoleh dari komite etik Rumah Sakit Islam Sultan Agung Semarang nomor 37/EC/KEPK/2020 mengenai kerahasiaan pasien serta persetujuan tertulis diperoleh dari pasien yang berkenan menjadi responden dalam penelitian ini.

Penentuan sampel digunakan perhitungan besar sampel dengan rumus Lemeshow. Kriteria eksklusi sampel penelitian ini adalah pasien berusia $\geq 40-70$ tahun, pasien Diabetes Melitus komplikasi stabil, pasien yang bersedia sebagai responden, pasien sudah pernah menerima obat minimal 1 bulan. Pengambilan sampel digunakan teknik nonprobability sampling yaitu dengan accidental sampling sehingga memberi kesempatan yang sama pada tiap anggota populasi yang kemudian dipilih menjadi sampel sesuai kriteria inklusi.

Variabel bebas pada penelitian ini adalah kepatuhan pasien. Variabel terikatnya adalah indeks glikemik kontrol (HbA1c). Pengumpulan data dilakukan di Rumah Sakit Islam Sultan Agung Semarang dengan memakai kuisioner ARMS sebagai alat ukur tingkat kepatuhan pasien, serta pemeriksaan indeks glikemik kontrol (kadar HbA1C).

\section{Hasil dan Pembahasan}

Hasil penelitian yang disajikan pada Tabel 1 menunjukan bahwa pasien Diabetes Melitus Tipe II didominasi oleh jenis kelamin perempuan (64,6\%). Hal tersebut disebabkan sebagian 
besar perempuan mudah mengalami stress sehingga mempengaruhi nilai kadar indeks glikemik kontrol. Perempuan merupakan faktor resiko penyakit Diabetes Melitus Tipe II disebabkan obesitas ataupun penggunaan kontrasepsi oral (Suryani et al., 2012). Perempuan lebih taat untuk minum obat sesuai petunjuk dan ketersediaan waktu dirumah lebih banyak dibandingkan dengan laki-laki (Srikartika et al., 2016). Pendidikan terakhir SLTA berjumlah $(53,1 \%) 51$ pasien, Sarjana S1 (36,5\%) 35 pasien dan Pendidikan SLTP (10,4\%) berjumlah 10 pasien. Penelitian Prakoso \& Ellena (2015) menyebutkan bahwa pasien yang berpendidikan lebih tinggi yaitu sarjana dan SLTA lebih patuh menjalani pengobatan terapi penyakit. Semakin tinggi tingkat pendidikan sesorang pasien akan semakin tinggi pula kesadaran dalam menjaga kesehatan menjalankan pengobatan. Lama menderita tertinggi $>12$ bulan berjumlah 57 pasien $(59,4 \%)$ dan $<3$ bulan 9 pasien $(9,4 \%)$, Semakin lama seseorang menderita suatu penyakit, maka semakin banyak pengalaman mengenai penyakit dan bentuk persepsi. Faktor yang berperan pembentukan persepsi merupakan cara berfikir atau kognitif, kepribadian, budaya yang dimiliki seseorang (Notoatmodjo, 2010).

Tabel 1. Ditribusi pasien menurut jenis kelamin, lama menderita DM, tingkat pendidikan di Rumah Sakit Islam Sultan Agung Semarang pada periode Agustus-September 2020.

\begin{tabular}{ccc}
\hline Karakteristik & Jumlah & $\%$ \\
\hline Jenis Kelamin & 34 & $35,4 \%$ \\
Laki-laki & 62 & $64,6 \%$ \\
Perempuan & & \\
Pendidikan & 10 & $10,4 \%$ \\
SLTP & 51 & $53,1 \%$ \\
SLTA & 35 & $36,5 \%$ \\
S1 & & \\
Lama Menderita & 9 & $9,4 \%$ \\
< Bln & 30 & $31,3 \%$ \\
3-11 Bln & 57 & $59,4 \%$ \\
\hline 12 Bln
\end{tabular}

Pengambilan data dimulai dari pemeriksaan HbA1c pada bulan pertama (PreCheck), dan dibulan berikutnya dilakukan pemeriksaan HbA1c (PostCheck). Hasil pemeriksaan HbA1c dapat dilihat pada Tabel 2. Hasil tersebut menunjukkan terdapat perbedaan signifikan dari $\mathrm{HbA1c}$ bulan pertama dan bulan kedua pemeriksaan dengan nilai median kadar HbA1c bulan pertama $7,80 \%$ dan bulan kedua $6,86 \%$ sehingga dapat disimpulkan bahwa perbedaan signifikan dari nilai kadar kadar HbA1c dengan hasil uji wilcoxon, dimana didapatkan nilai $\mathrm{p}$ 0,000 ( $\mathrm{p}<0,05)$. Hal ini diperkuat dengan bukti penelitian yang dilakukan Nanda et al. (2018) mengemukakan adanya perbedaan indeks glikemik sebelum mengkonsumsi obat dengan setelah mengkonsumsi obat. Kemudian, Menurut penelitian Lee et al. (2017), terdapat perbedaan output klinik pasien yang patuh meminum obat antidiabetik oral sehingga, kepatuhan pasien dalam meminum obat merupakan faktor kuat untuk ketercapainya output klinik yang 
terkontrol. Selain berdasarkan penelitian tersebut, menurut Zulfhi \& Muflihatin (2020), Terdapat penurunan nilai kontrol glikemik pasien Diabetes Melitus sebelum dan sesudah meminum obat yang di teliti pada pasien Diabates Melitus Tipe II di Rawat inap RSUD Abdul Wahab Sjahranie Samarinda.

Tabel 2. Hasil indeks glikemik pada pasien Diabetes Melitus tipe II di Rumah Sakit Islam Sultan Agung Semarang pada periode Agustus-September 2020.

\begin{tabular}{ccc}
\hline Indek Glikemik & Median (Min-Max) & Nilai $\boldsymbol{p}$ \\
\hline HbA1c Sebelum $(\mathrm{n}=96)$ & $7,80(5,30-13,90)$ & \multirow{2}{*}{0,000} \\
\hline HbA1c Sesudah $(\mathrm{n}=96)$ & $6,86(5,02-14,50)$ & \\
\hline
\end{tabular}

Pengukuran tingkat kepatuhan penggunaan obat menggunakan kuisioner ARMS jangka waktu satu bulan. Pada tingkat kepatuhan penggunaan obat pasien Diabetes Melitus tipe II dilakukan dengan perhitungan skor ARMS (Adherance Refill Medication Scale). Kuisioner ARMS dikembangkan untuk pengukuran kepatuhan penggunaan obat yang telah diresepkan dan telah dikaitkan dengan tindakan obyektif (Mayberry et al., 2013). Pada hasil kuisioner ARMS terbagi menjadi tiga kategori yaitu kategori kepatuhan rendah apabila skor ARMS adalah 33-48, kategori sedang dengan skor 17-32, dan kategori tinggi bila skor ARMS adalah 12-16. Semakin rendah skor ARMS menunjukan hasil kepatuhan penggunaan obat tinggi. Sebaliknya, apabila skor ARMS yang tinggi menunjukan kepatuhan dalam penggunaan obat yang rendah (Kripalani et al., 2009). Pada penelitian ini, dari total sampel penelitian 96 pasien didapatkan jumlah pasien dengan kategori tinggi sebanyak 58 pasien, kategori sedang sebanyak 27 pasien dan kategori rendah sebanyak 11 pasien.

Tabel 3. Kepatuhan penggunaan obat dengan indeks glikemik kontrol pada pasien Diabetes Melitus tipe II di Rumah Sakit Islam Sultan Agung Semarang pada periode AgustusSeptember 2020 .

\begin{tabular}{|c|c|c|c|c|c|}
\hline \multirow{2}{*}{\multicolumn{2}{|c|}{ Kepatuhan }} & \multicolumn{3}{|c|}{ HbA1C } & \multirow[b]{2}{*}{ Nilai $p$} \\
\hline & & $\begin{array}{c}\text { Tidak } \\
\text { Terkontrol }\end{array}$ & Terkontrol & Total & \\
\hline \multirow{2}{*}{ Rendah } & $\mathrm{N}$ & 11 & 0 & 11 & \multirow{6}{*}{0,000} \\
\hline & $\%$ & $100 \%$ & $0 \%$ & $100 \%$ & \\
\hline \multirow{2}{*}{ Sedang } & $\mathrm{N}$ & 22 & 5 & 27 & \\
\hline & $\%$ & $81,5 \%$ & $18,5 \%$ & $100 \%$ & \\
\hline \multirow{2}{*}{ Tinggi } & $\mathrm{N}$ & 0 & 58 & 58 & \\
\hline & $\%$ & $0 \%$ & $100 \%$ & $100 \%$ & \\
\hline
\end{tabular}

Tingkat kepatuhan pasien berdasarkan kategori HbA1c (Tabel 3) didapatkan bahwa tingkat kepatuhan rendah dengan HbAlc tidak terkontrol sebanyak 11 pasien (100\%) dan 0 pasien $(0 \%)$ kategori HbA1c terkontrol, tingkat kepatuhan sedang dalam kategori HbA1c tidak terkontrol 22 orang $(81,5 \%)$ dalam kategori HbA1c terkontrol 5 orang (18,5\%), tingkat kepatuhan tinggi dalam kategori HbA1c tidak terkontrol 0 orang $(0 \%)$ dan $\mathrm{HbA} 1 \mathrm{C}$ terkontrol 58 orang $(100 \%)$. 
Terapi pengobatan penyakit Diabetes Melitus tipe II dapat dikatakan berhasil apabila adanya kepatuhan dalam penggunaan obat. Kepatuhan penggunaan obat akan memberikan dampak pengaruh terhadap indek glikemik pasien Diabetes Melitus Tipe II. Kepatuhan penggunaan obat merupakan suatu sikap pasien dalam menerima, melakukan pengobatan terapi dalam waktu tertentu (Edi, 2020). Hasil penelitian ini juga mendukung penelitian sebelumnya bahwa peningkatan kepatuhan pasien berpengaruh signifikan pada kontrol kadar gula darah pasien (Fatiha \& Sabiti, 2021). Kepatuhan penggunaan obat dipengaruhi beberapa faktor yaitu pasien yang tidak atau terlambat mendapatkan obat, pasien sengaja atau tidak sengaja lupa mengkonsumsi obat serta efek samping suatu obat yang menyebabkan kualitas hidup buruk pada pasien sehingga pasien malas untuk menlanjutkan pengobatan (García-Pérez et al., 2013)

Pengolahan data tersebut menggunakan uji chi-square yang menenjukan $p$ value $<0,05$ bahwa terdapat hubungan yang signifikan antara kepatuhan penggunaan obat dengan indeks glikemik kontrol HbA1C pada Pasien Diabetes Mellitus tipe II. Salah satu ketidakpatuhan penggunaan obat terhadap pasien dengan kategori sedang dan kategori rendah yakni, kurangnya inisiatif pasien untuk membeli obat yang kurang jumlahnya secara mandiri di apotek, hal tersebut juga dipengaruhi tingkat ekonomi pasien Diabetes Mellitus Tipe II.

Keterbatasan pada penelitian ini adalah tidak mengkaji kaitan antara komorbid yang diderita pasien dengan kontrol glikemiknya. Terapi yang diperoleh untuk penanganan komorbid memungkinkan untuk berpengaruh pada kontrol gula darahnya. Sebuah studi menyebutkan bahwa penggunaan simvastatin pada pasien DM berkorelasi dengan peningkatan kadar gula darah puasa (Farida \& Putri, 2016). Studi lebih lanjut dibutuhkan untuk melengkapi keterbatasan pada penelitian ini.

\section{Kesimpulan}

Hasil penelitian ini menunjukan bahwa indeks glikemik kontrol HbAlc pada pasien Diabetes Melitus type II di Rumah Sakit Islam Sultan Agung Semarang menunjukan nilai $p$ $0,000(p<0,05)$ bahwa terdapat hubungan kepatuhan penggunaan obat dengan kadar HbA1c.

\section{Ucapan Terima Kasih}

Ucapan Terima kasih penulis bagi LPPM Universitas Islam Sultan Agung Semarang (Unissula) yang telah mendanai kegiatan ini melalui skema Program Penelitian Internal Tahun 2020. Terima kasih kepada pihak terkait Rumah Sakit Islam Sultan Agung Semarang yang telah memberikan izin sehingga peneliti dapat melaksanakan kegiatan dengan baik dan lancar.

\section{Deklarasi Konflik Kepentingan}

Semua penulis menyatakan tidak ada konflik kepentingan terhadap naskah ini. Penulis pertama tidak ada konflik kepentingan terhadap naskah artikel ini. 


\section{Daftar Pustaka}

Adikusuma, W., dan Qiyaam, N. (2017). Antidiabetik Oral Terhadap Kadar Hemoglobin Terglikasi ( HbA1c) Pada Pasien Diabetes Melitus. Jurnal Ilmiah Ibnu Sina, 2(2), 279286.

Aini, D. N. (2016). Faktor yang Berhubungan dengan Kepatuhan Penderita Diabetes Melitus Dalam Menjalankan Diet. Skripsi. Program Studi Ilmu Keperawatan STIKES Widya Husada Semarang.

Edi, I. G. M. S. (2020). Faktor-Faktor Yang Mempengaruhi Kepatuhan Pasien Pada Pengobatan. Jurnal Ilmiah Medicamento, 1(1), 1-8. https://doi.org/10.36733/medicamento.v1i1.719.

Ernawati, E. (2010). Kemampuan Melakukan Penatalaksanaan Hipoglikemia Berdasarkan Karakteristik dan Pengetahuan Pasien Diabetes Melitus. Jurnal Keperawatan Indonesia, 13(1), 7-13. https://doi.org/10.7454/jki.v13i1.224.

Farida, Y., dan Putri, C. (2016). Efek penggunaan simvastatin terhadap kenaikan gula darah puasa pasien Diabetes Melitus Tipe 2. JPSCR: Journal of Pharmaceutical Science and Clinical Research, 1(1), 58-65. https://doi.org/10.20961/JPSCR.V1I1.696.

Fatiha, C. N., dan Sabiti, F. B. (2021). Peningkatan Kepatuhan Minum Obat Melalui Konseling Apoteker pada Pasien Diabetes Mellitus Tipe 2 di Puskesmas Halmahera Kota Semarang. JPSCR: Journal of Pharmaceutical Science and Clinical Research, 6(1), 41-48. https://doi.org/10.20961/JPSCR.V6I1.39297.

García-Pérez, L. E., Álvarez, M., Dilla, T., Gil-Guillén, V., dan Orozco-Beltrán, D. (2013). Adherence to therapies in patients with type 2 diabetes. Diabetes Therapy, 4(2), 175-194. https://doi.org/10.1007/s13300-013-0034-y.

Katadi, S., Andayani, T. M., dan Endarti, D. (2019). The Correlation of Treatment Adherence with Clinical Outcome and Quality of Life in Patients with Type 2 Diabetes. JURNAL MANAJEMEN DAN PELAYANAN FARMASI (Journal of Management and Pharmacy Practice), 9(1), 19. https://doi.org/10.22146/jmpf.42927.

Kripalani, S., Risser, J., Gatti, M. E., dan Jacobson, T. A. (2009). Development and evaluation of the Adherence to Refills and Medications scale (ARMS) among low-literacy patients with chronic disease. Value in Health, 12(1), 118-123. https://doi.org/10.1111/j.15244733.2008.00400.x.

Lee, C. S., Tan, J. H. M., Sankari, U., Koh, Y. L. E., dan Tan, N. C. (2017). Assessing oral medication adherence among patients with type 2 diabetes mellitus treated with polytherapy in a developed Asian community: A cross-sectional study. BMJ Open, 7(9), 1-7. https://doi.org/10.1136/bmjopen-2017-016317.

Mayberry, L. S., Gonzalez, J. S., Wallston, K. A., Kripalani, S., dan Osborn, C. Y. (2013). The ARMS-D out performs the SDSCA, but both are reliable, valid, and predict glycemic control. Diabetes Research and Clinical Practice, 102(2), 96-104. https://doi.org/10.1016/j.diabres.2013.09.010.

Nanda, O. D., Wiryanto, B., dan Triyono, E. A. (2018). Hubungan Kepatuhan Minum Obat Anti Diabetik dengan Regulasi Kadar Gula Darah pada Pasien Perempuan Diabetes Mellitus. Amerta Nutrition, 2(4), 340. https://doi.org/10.20473/amnt.v2i4.2018.340-348

Nurul, P. (2014). Hubungan Antara Kepatuhan Penggunaan Obat Dan Keberhasilan Terapi Pada Pasien Diabetes Mellitus Instalasi Rawat Jalan Di Rs X Surakarta, Skripsi, Fakultas Farmasi.Universitas Muhammadiyah Surakarta.

Notoatmodjo, S. (2010). Promosi Kesehatan, Teori \& Aplikasi, ed. revisi 2010. In Jakarta: Rineka Cipta. https://doi.org/10.1108/JMTM-03-2018-0075.

PERKENI. (2019). Pedoman Pengelolaan Dan Pencegahan Diabetes Melitus Tipe 2 Di Indonesia, Jakarta : Perkumpulan Endokrinologi Indonesia.

Prakoso, D. A., dan Ellena, N. (2015). Hasil Guna Edukasi Diabetes Menggunakan Telemedicine terhadap Kepatuhan Minum Obat Diabetisi Tipe 2. Mutiara Medika: Jurnal 
Kedokteran

Dan

Kesehatan,

15(1),

$15-21$. https://doi.org/10.18196/MMJKK.V15I1.2489.

Sivasubramanian, V., Jetty, K., dan Kumar, S. S. (2019). Correlation of HbA1c with urinary ACR, serum creatinine and eGFR in type- 2 diabetes mellitus at Puducherry, South India. International Journal of Research in Medical Sciences, 7(5), 1924-1928. https://doi.org/10.18203/2320-6012.IJRMS20191702.

Srikartika, V. M., Cahya, A. D., Suci, R., Hardiati, W., dan Srikartika, V. M. (2016). Analisis Faktor Yang Mempengaruhi Kepatuhan Penggunaan Obat Pasien Diabetes Melitus Tipe 2 the Analysis of the Factors Affecting Medication Adherence in Patients. Garuda Jurnal, 6(2011), 205-212.

Suryani, N. M., Wirasuta, I. M. A. G., dan Susanti, N. M. P. (2013). Pengaruh konseling obat dalam home care terhadap kepatuhan pasien diabetes melitus tipe 2 dengan komplikasi hipertensi. Jurnal Farmasi Udayana, 2(3), 6-12.

Zulfhi, H dan Muflihatin, S. K. (2020). Hubungan Kepatuhan Minum Obat dengan Terkendalinya Kadar Gula Darah pada Pasien DM Tipe II di Irna RSUD Abdul Wahab Sjahranie Samarinda. Borneo Student Research (BSR), 1(3), 1679-1686.

\section{(c) (1) (2)}

(C) 2021 by the authors. Submitted for possible open access publication under the terms and conditions of the Creative Commons Attribution-ShareAlike 4.0 International (CC BY-SA 4.0) license (https://creativecommons.org/licenses/by-sa/4.0/). 